Article

\title{
Proapoptotic Activity of Achillea membranacea Essential Oil and Its Major Constituent 1,8-Cineole against A2780 Ovarian Cancer Cells
}

\author{
Ashraf N. Abdalla ${ }^{1}$, Usama Shaheen ${ }^{1,2}$, Qasem M. A. Abdallah ${ }^{3,4}$, Guido Flamini ${ }^{5, *}$, \\ Majdi M. Bkhaitan 1,6 $(D)$, Mohamed I. S. Abdelhady ${ }^{1,7}\left(\mathbb{D}\right.$, Roberta Ascrizzi $^{5}(\mathbb{D}$ and \\ Ammar Bader 1,*D \\ 1 Faculty of Pharmacy, Umm Al-Qura University, Makkah 21955, Saudi Arabia; \\ anabdrabo@uqu.edu.sa (A.N.A.); usamayosef2003@yahoo.com (U.S.); \\ bariumchloride@hotmail.com (M.M.B.); mohibrahem@yahoo.com (M.I.S.A.)

\begin{abstract}
Among the hundreds of reported Achillea species, A. membranacea (Labill.) DC. is one of the six that grow in Jordan. Many species of this genus are used in folk medicine to treat a variety of ailments and several biological and pharmacological activities have been ascribed to their essential oil (EO). For this study, the EO obtained from a specimen of A. membranacea grown in Jordan was analyzed by GC-MS. Ninety-six compounds were detected, of which oxygenated monoterpenes was the predominant class $(47.9 \%)$, followed by non-terpene derivatives $(27.9 \%)$, while sesquiterpenes represented $14.2 \%$ of the total composition. The most abundant compound in the EO was 1,8-cineole $(21.7 \%)$. The cytotoxic activity of the EO was evaluated against three cancer cell lines (MCF7, A2780 and HT29), and one normal fibroblast cell line (MRC5) by MTT assay. Significant growth inhibition was observed in EO-exposed A2780 and HT29 cells $\left(\mathrm{IC}_{50}=12.99\right.$ and $14.02 \mu \mathrm{g} / \mathrm{mL}$, respectively), while MCF7 and MRC5 were less susceptible. The EO induced apoptosis and increased the preG1 events in A2780 cells. 1,8-Cineole, the major constituent of the EO, exhibited submicromolar cytotoxicity against A2780 cells, and was 42 times more selective against MRC5 cells. Its cytotoxicity against A2780 cells was comparable with that of doxorubicin, but 1,8-cineole was more selective for MRC5 normal cells. Interestingly, 1,8-cineole enhanced apoptosis in A2780, and caused a remarkable dose-dependent increase in preG1 events. Thus, 1,8-cineole has demonstrated promising cytotoxic and proapoptotic properties.
\end{abstract}

Keywords: Asteraceae; essential oil; GC-EI-MS; 1,8-cineole; cytotoxicity; apoptosis; cell cycle

\section{Introduction}

Medicinal plants and their constituents have countless biological properties, based mainly on their ability to interact with key enzymes linked to several ailments, including: cancer, diabetes, inflammation, hypertension and Alzheimer's disease [1-5]. Recently, EOs have caught the attention of 
scientists due to their ability to prevent and treat cancer, as well as their state-of-the-art application in the most advanced and sophisticated technologies in nanoscience [6-8].

The genus Achillea includes over a hundred species and subspecies, which are distributed in the Northern hemisphere [9]. The use of the inflorescence, as well as the whole plant, of many of these species has a long-established role in folk medicine to treat a wide range of ailments that mainly affect the digestive system. It takes various application forms, which differ depending on the geographical area [10-13]. Besides their medicinal properties, some Achillea species are also cultivated as ornamental plants.

A. membranacea (Labill.) DC. is one of the six species reported in Jordan [14]: it is distributed in the Irano-Turanian phytogeographic region, which includes Jordan, Palestine, Syria, Lebanon, Iraq and Turkey [15]. A. membranacea is a perennial herb. It has numerous stems $(25-50 \mathrm{~cm})$, is lignified in the basal section, exhibits pannose, linear, sessile and pinnatisect $(1.5-6 \mathrm{~cm} \times 0.3-0.6 \mathrm{~cm})$ leaves, and has a capitula up to $20 \mathrm{~mm}$ and yellow ray florets [15].

The EO of many Achillea species possesses several biological and pharmacological activities. It is antimicrobial, antimalarial, insecticidal, phytotoxic, anti-inflammatory and antihemorrhoidal [16-20]. Anticancer and cytotoxic effects were reported for the extracts of some Achillea species, including $A$. clavennae L. and A. millefolium L., the iso-seco-guaianolide, which was isolated from A. clavennae L., exhibited potent antiproliferative and apoptotic effects on U251 and glioma cell lines, with a potency comparable to that of cisplatin [21], mediated by its oxidative and mitotic activities. Another compound, casticin, showed multiple antitumor activities. Casticin, which was isolated from A. millefolium L. through HPLC, showed cytotoxic, early apoptosis, $\mathrm{G}_{2} / \mathrm{M}$ cell cycle arrest and consequently disruption of the mitotic spindle in two MCF7 sublines [22]. In a previous study, the methanol extract of $A$. membranacea exerted a moderate cytotoxic effect upon Jurkat cells (T-cell leukemia) using the MTT assay [23].

As a part of an ongoing research program on the Middle Eastern plants bioactivity [24], we have selected $A$. membranacea for this study with the aim to analyze the composition of the EO of $A$. membranacea collected in Jordan and to evaluate its cytotoxic activity against breast (MCF7), ovary (A2780) and colon (HT29) cancer cell lines, and non-tumorigenic human fetal lung fibroblasts (MRC5 cells). Moreover, its effects on apoptosis and cell cycle effect of the EO on A2780 cells were investigated. Beside the EO, we have tested the cytotoxicity, induction of apoptosis and cell cycle effect of its major constituent, 1,8-cineole, against A2780 cell line, disclosing the possible action mechanism of the EO and its major constituent.

\section{Results}

\subsection{A. membranacea Essential Oil Composition}

The complete composition of the essential oil (EO) hydrodistilled from A. membranacea aerial parts is reported in Table 1. A total of 96 compounds were identified, accounting for $92.0 \%$ of the total composition, which was chiefly made up of monoterpenes. In particular, over $45 \%$ of the total was constituted by oxygenated monoterpenes, of which 1,8-cineole was the most represented: exhibiting a relative abundance of $21.7 \%$, it was also the most abundant compound in the EO. Other quantitatively relevant compounds of this chemical class were borneol and trans-pinocarveol, whose relative concentrations were $4.3 \%$ and $3.1 \%$, respectively. Non-terpene derivatives accounted for up to $22.4 \%$, making them the second most abundant detected chemical class of compounds in the EO. Among them, aldehydes prevailed (12.7\%), with decanal and (Z)-4-decenal being the most abundant; hydrocarbons followed, accounting for up to $5.0 \%$. Sesquiterpenes were almost equally represented by their hydrocarbon and oxygenated forms (6.7\% and $6.9 \%$, respectively). Among the former, $\alpha$-cadinene was the most represented, while spathulenol was the most abundant of the latter class. Apocarotenes and phenylpropanoids followed, with relative concentrations of $4.2 \%$ and $3.9 \%$, respectively. 
Table 1. Complete composition of $A$. membranacea essential oil (EO).

\begin{tabular}{|c|c|c|}
\hline Constituents & 1.r.i. ${ }^{a}$ & Relative Abundance (\%) \\
\hline (E)-2-hexenal & 855 & 1.7 \\
\hline 1-hexanol & 868 & 0.4 \\
\hline heptanal & 900 & 0.4 \\
\hline$(E, E)-2,4$-hexadienal & 910 & $\operatorname{tr}^{b}$ \\
\hline$\alpha$-thujene & 931 & $\operatorname{tr}$ \\
\hline$\alpha$-pinene & 939 & 0.7 \\
\hline camphene & 953 & $\operatorname{tr}$ \\
\hline (Z)-2-heptenal & 959 & 0.2 \\
\hline benzaldehyde & 961 & 0.8 \\
\hline 1-heptanol & 969 & $\operatorname{tr}$ \\
\hline sabinene & 976 & $\operatorname{tr}$ \\
\hline 1-octen-3-ol & 978 & 0.2 \\
\hline 6-methyl-5-hepten-2-one & 985 & 0.7 \\
\hline 2,3-dehydro-1,8-cineole & 991 & 1.3 \\
\hline octanal & 1002 & 1.6 \\
\hline$\alpha$-phellandrene & 1005 & 0.4 \\
\hline$(E, E)$-2,4-heptadienal & 1015 & 0.4 \\
\hline$\alpha$-terpinene & 1018 & 0.2 \\
\hline p-cymene & 1027 & 0.3 \\
\hline 1,8-cineole & 1035 & 21.7 \\
\hline (Z)- $\beta$-ocimene & 1041 & $\operatorname{tr}$ \\
\hline 3-octen-2-one & 1042 & $\operatorname{tr}$ \\
\hline phenyl acetaldehyde & 1045 & 1.5 \\
\hline$(E, E)-3,5$-octadien-2-one & 1090 & 0.4 \\
\hline linalool & 1099 & 1.1 \\
\hline$\alpha$-thujone & 1102 & 2.3 \\
\hline cis- $p$-menth-2-en-1-ol & 1123 & 2 \\
\hline$\alpha$-campholenal & 1127 & $\operatorname{tr}$ \\
\hline cis- $p$-mentha-2,8-dien-1-ol & 1139 & $\operatorname{tr}$ \\
\hline trans-pinocarveol & 1140 & 3.1 \\
\hline camphor & 1145 & 1.6 \\
\hline$(E)$-2-nonenal & 1162 & 0.7 \\
\hline pinocarvone & 1164 & 1.0 \\
\hline borneol & 1166 & 4.3 \\
\hline 4-terpineol & 1178 & 0.9 \\
\hline$p$-cymen-8-ol & 1185 & 0.3 \\
\hline cryptone & 1186 & $\operatorname{tr}$ \\
\hline$\alpha$-terpineol & 1190 & 1.4 \\
\hline (Z)-4-decenal & 1194 & 2.2 \\
\hline myrtenal & 1195 & 0.8 \\
\hline safranal & 1200 & 0.4 \\
\hline decanal & 1205 & 2.5 \\
\hline trans-carveol & 1219 & $\operatorname{tr}$ \\
\hline$\beta$-cyclocitral & 1223 & 0.3 \\
\hline isobornyl formate & 1233 & 0.3 \\
\hline piperitone & 1254 & 2.1 \\
\hline linalyl acetate & 1258 & 0.7 \\
\hline cis-chrysanthenyl acetate & 1263 & $\operatorname{tr}$ \\
\hline geranial & 1272 & $\operatorname{tr}$ \\
\hline isobornyl acetate & 1286 & 0.3 \\
\hline thymol & 1291 & 0.3 \\
\hline carvacrol & 1300 & 0.4 \\
\hline$(E, E)$-2,4-decadienal & 1316 & 0.2 \\
\hline
\end{tabular}


Table 1. Cont.

\begin{tabular}{|c|c|c|}
\hline Constituents & 1.r.i. ${ }^{a}$ & Relative Abundance (\%) \\
\hline methyl decanoate & 1326 & $\operatorname{tr}$ \\
\hline hexyl tiglate & 1333 & 0.7 \\
\hline trans-piperitol acetate & 1346 & $\operatorname{tr}$ \\
\hline$\alpha$-terpinyl acetate & 1351 & $\operatorname{tr}$ \\
\hline eugenol & 1358 & $\operatorname{tr}$ \\
\hline neryl acetate & 1367 & $\operatorname{tr}$ \\
\hline$\alpha$-copaene & 1376 & $\operatorname{tr}$ \\
\hline (E)- $\beta$-damascenone & 1382 & 0.9 \\
\hline$n$-tetradecane & 1400 & 0.2 \\
\hline methyl eugenol & 1403 & $\operatorname{tr}$ \\
\hline dodecanal & 1408 & $\operatorname{tr}$ \\
\hline$\beta$-caryophyllene & 1418 & 0.4 \\
\hline$(E)$ - $\alpha$-ionone & 1428 & 0.3 \\
\hline cabreuva oxide A & 1447 & $\operatorname{tr}$ \\
\hline (E)-geranyl acetone & 1454 & 1.7 \\
\hline$\beta$-santalene & 1462 & 1.2 \\
\hline cabreuva oxide D & 1480 & 0.8 \\
\hline germacrene D & 1485 & 0.9 \\
\hline$(E)$ - $\beta$-ionone & 1485 & 0.6 \\
\hline cis- $\beta$-guaiene & 1492 & 0.9 \\
\hline bicyclogermacrene & 1494 & 0.4 \\
\hline n-pentadecane & 1500 & $\operatorname{tr}$ \\
\hline tridecanal & 1518 & 0.3 \\
\hline myristicin & 1520 & 3.3 \\
\hline 7-epi-a-selinene & 1522 & 0.3 \\
\hline$\alpha$-cadinene & 1538 & 2.6 \\
\hline ledol & 1565 & 0.3 \\
\hline trans-nerolidol & 1566 & 0.5 \\
\hline spathulenol & 1576 & 2.7 \\
\hline caryophyllene oxide & 1581 & 0.8 \\
\hline n-hexadecane & 1600 & 0.4 \\
\hline$\beta$-oplopenone & 1606 & 0.4 \\
\hline dill apiole & 1621 & 0.6 \\
\hline$\tau$-cadinol & 1641 & 0.4 \\
\hline$\beta$-eudesmol & 1649 & 0.7 \\
\hline intermedeol & 1667 & 0.3 \\
\hline n-heptadecane & 1700 & $\operatorname{tr}$ \\
\hline pentadecanal & 1717 & 0.2 \\
\hline hexahydrofarnesylacetone & 1845 & $\operatorname{tr}$ \\
\hline (3Z)-cembrene A & 1959 & 0.4 \\
\hline linoleic acid ethyl ester & 2160 & 2.3 \\
\hline 1-pentacosene & 2400 & 3.8 \\
\hline$n$-pentacosane & 2500 & 0.6 \\
\hline \multicolumn{2}{|c|}{ Monoterpene hydrocarbons } & 1.6 \\
\hline \multicolumn{2}{|c|}{ Oxygenated monoterpenes } & 45.9 \\
\hline \multicolumn{2}{|c|}{ Sesquiterpene hydrocarbons } & 6.7 \\
\hline \multicolumn{2}{|c|}{ Oxygenated sesquiterpenes } & 6.9 \\
\hline \multicolumn{2}{|c|}{ Diterpene hydrocarbons } & 0.4 \\
\hline \multicolumn{2}{|c|}{ Apocarotenes } & 4.2 \\
\hline \multicolumn{2}{|c|}{ Phenylpropanoids } & 3.9 \\
\hline \multicolumn{2}{|c|}{ Other non-terpene derivatives } & 22.4 \\
\hline \multicolumn{2}{|c|}{ Total identified $(\%)$} & 92.0 \\
\hline
\end{tabular}

${ }^{\mathrm{a}}$ Linear retention indices on a DB-5 capillary column; ${ }^{\mathrm{b}}$ Traces, $<0.1 \%$. 


\subsection{Cytotoxic Activity}

The cytotoxic activity of A. membranacea EO against the tested cell lines is reported in Table 2. It induced significant growth inhibition in ovarian (A2780) and colorectal (HT29) cells $\left(\mathrm{IC}_{50}=12.99\right.$ and $14.02 \mu \mathrm{g} / \mathrm{mL}$, respectively). Negligible toxicity was noticed, however, in treated breast cancer (MCF7) and human fetal lung fibroblast (MRC5) cells $\left(\mathrm{IC}_{50}=50.86 \mu \mathrm{g} / \mathrm{mL}\right.$ and $\mathrm{IC}_{50}=49.25 \mu \mathrm{g} / \mathrm{mL}$, respectively). The EO was four times more selective for A2780 and HT29 cell lines compared to MRC5 cells $\left(\mathrm{IC}_{50}=49.25 \mu \mathrm{g} / \mathrm{mL}\right)$. The major component, 1,8-cineole, was selected for further cytotoxicity assessments. 1,8-Cineole showed remarkable cytotoxicity compared to A. membranacea EO in A2780 cells $(0.26 \mu \mathrm{M})$; its selectivity was 42 times higher for A2780 compared to MRC5 cells $(10.5 \mu \mathrm{M})$. Using the same cell lines, the selectivity profile of 1,8-cineole was better compared to doxorubicin, as the latter showed only a twofold improvement in selectivity (Table 3).

Table 2. Cytotoxic activity of A. membranacea essential oil against three cancer cell lines and one normal fibroblast (MTT $72 \mathrm{~h}, \mathrm{IC}_{50} \pm \mathrm{SD} \mu \mathrm{g} / \mathrm{mL}$ ).

\begin{tabular}{cccc}
\hline MCF7 & A2780 & HT29 & MRC5 \\
\hline $50.86 \pm 10.14$ & $12.99 \pm 2.96$ & $14.02 \pm 4.89$ & $49.25 \pm 1.27$ \\
\hline
\end{tabular}

Table 3. Cytotoxic activity of 1,8-cineole and doxorubicin against A2780 and MRC5 cells (MTT $72 \mathrm{~h}$, $\left.\mathrm{IC}_{50} \pm \mathrm{SD} \mu \mathrm{M}\right)$.

\begin{tabular}{ccc}
\hline & A2780 & MRC5 \\
\hline 1,8-Cineole & $0.26 \pm 0.04$ & $10.50 \pm 1.70$ \\
\hline doxorubicin & $0.14 \pm 0.02$ & $0.21 \pm 0.03$ \\
\hline
\end{tabular}

\subsection{Induction of Cell Apoptosis}

In order to explore the mechanism of action, the induction of apoptosis by A. membranacea EO on A2780 cells was investigated at the same time-point of testing the cytotoxicity ( $72 \mathrm{~h}$ ) to confirm its apoptotic vs necrotic properties. The EO showed a dose-dependent increase of combined early and late apoptosis in A2780 cells, although its effect at the 25 and $50 \mu \mathrm{g} / \mathrm{mL}$ was close. The EO caused mainly a late apoptosis compared to early apoptosis in A2780 cells. There was also an increase in the necrotic events from $4 \%$ to $20 \%$ at the three doses (Figure 1A,B). The situation was inverted when 1,8-cineole was used alone in A2780 cells at the same time-point, as it caused a dose-dependent increase in early apoptosis up to $37 \%$ at $1 \mu \mathrm{M}$, with only $2 \%$ late apoptosis and negligible necrotic effect (Figure 1C,D). 
A
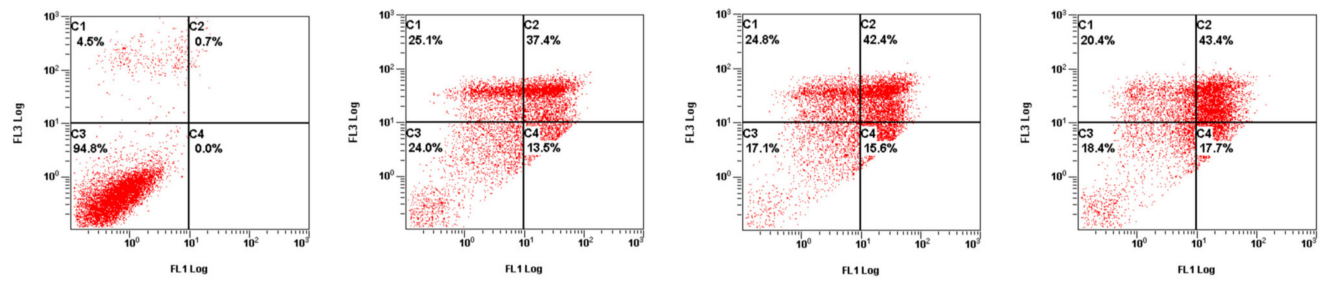

B

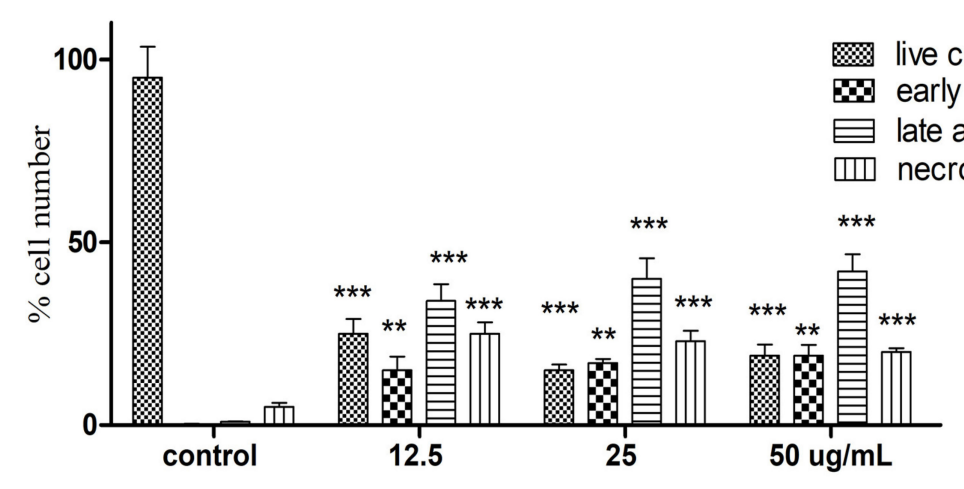

C
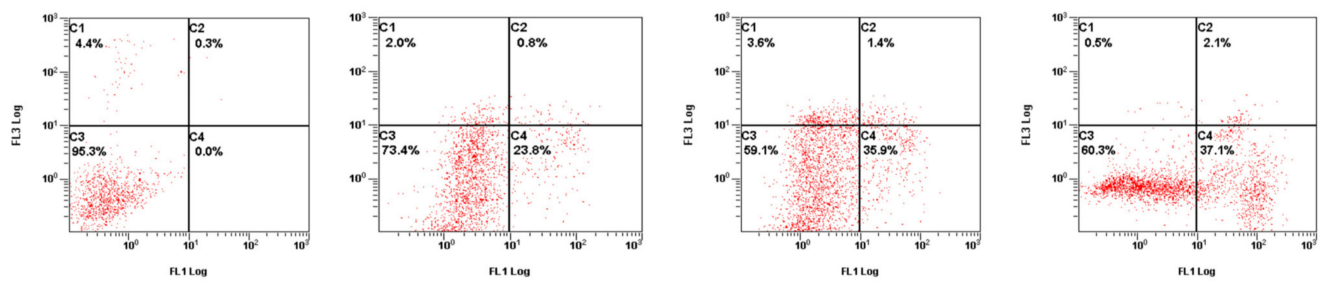

D

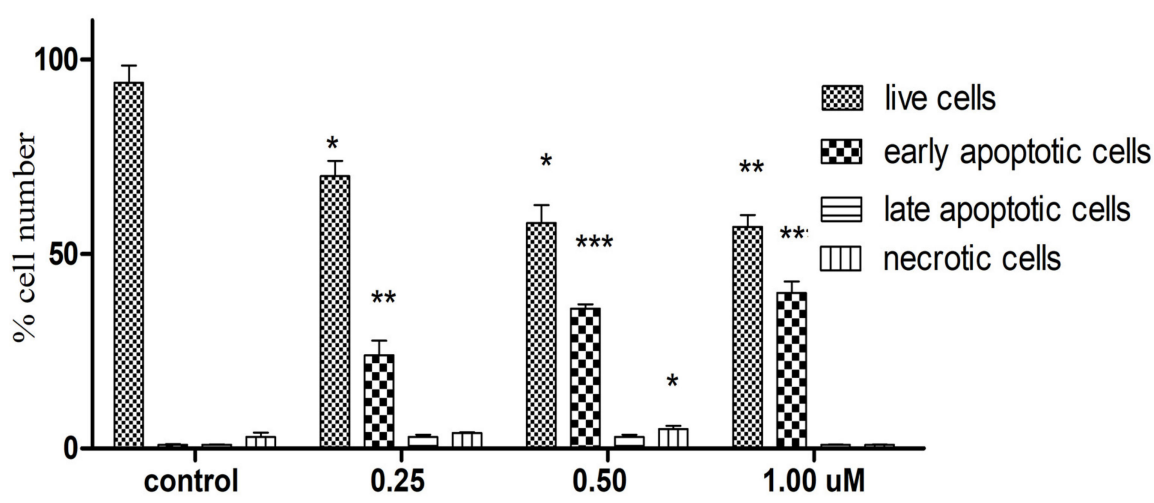

Figure 1. Detection of early and late apoptosis in A2780 cells $(72 \mathrm{~h})$ treated with $A$. membranacea essential oil $(\mathbf{A}, \mathbf{B})$, and 1,8-cineole $(\mathbf{C}, \mathbf{D})$. Dot histograms $(\mathbf{A}, \mathbf{C})$ : $\mathbf{x}$-axis: annexin $\mathrm{V}$, y-axis: propidium iodide. C1: necrotic cells, C2: late apoptotic cells, C3: live cells, C4: early apoptotic cells. Data shown are \% mean \pm SD $(n=3)$. All experiments were performed three times. Statistical differences, compared to untreated control cells, were assessed by a one-way ANOVA with the Tukey's post-hoc multiple comparison test. $p<0.05\left(^{*}\right), p<0.01\left(^{* *}\right)$ and $p<0.001\left(^{* * *}\right)$ were taken as significant.

\subsection{Perturbation of the Cell Cycle}

The cell-cycle analysis on A. membranacea EO treated A2780 cells was performed (72 h), showing a non-dose dependent slight $S$ arrest at 12.5 and $50 \mu \mathrm{g} / \mathrm{mL}$. Moreover, the EO caused a $10 \%$ increase 
in the preG1 at the expense of $\mathrm{G}_{1}$ and $\mathrm{G}_{2} / \mathrm{M}$ decreased events (Figure 2A,B). 1,8-Cineole also caused $\mathrm{S}$ phase arrest only at $12.5 \mu \mathrm{g} / \mathrm{mL}$, but it induced a 15-20-fold sharp dose dependent increase in the preG $_{1}$ apoptotic events in A2780 cells (Figure 2C,D).

A

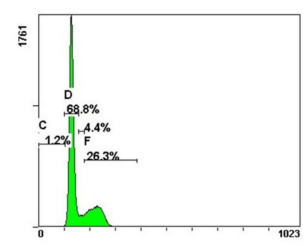

DNA

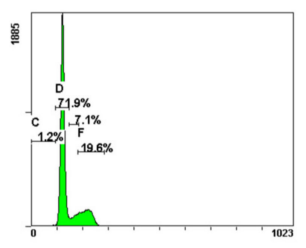

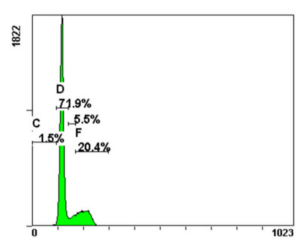

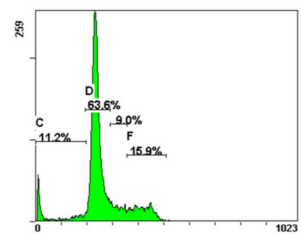

DNA

B

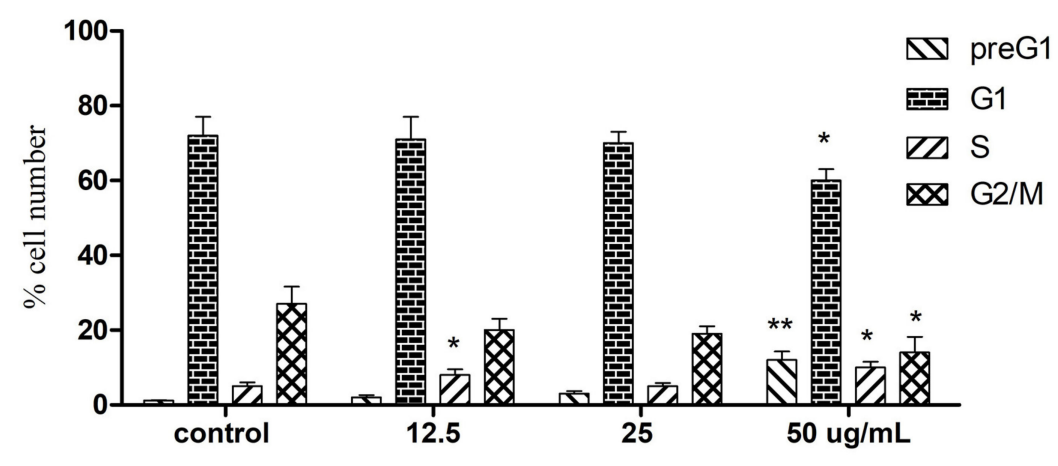

C
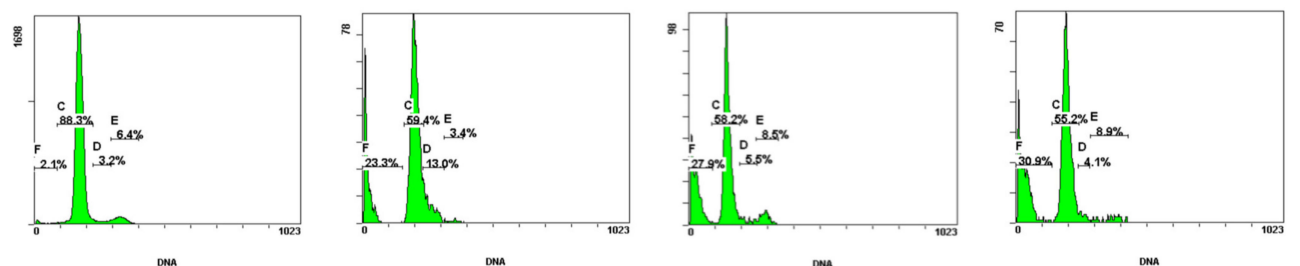

D

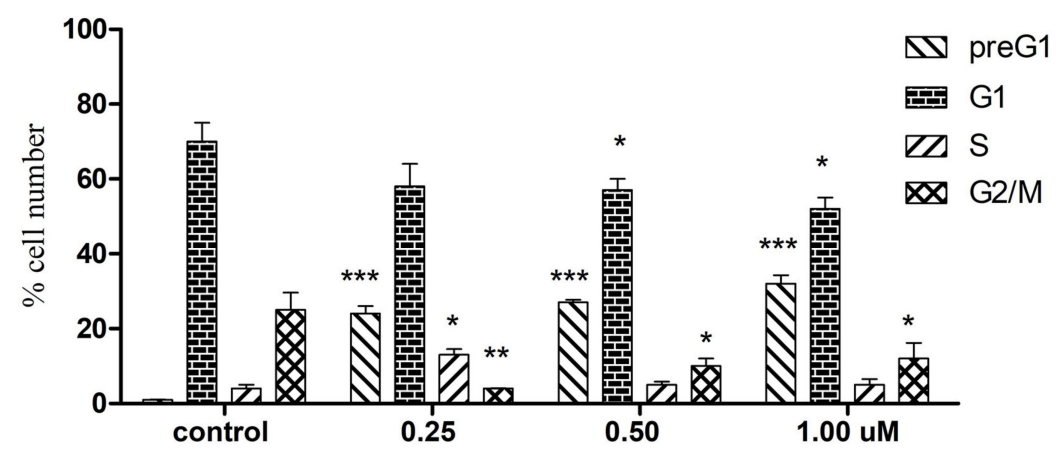

Figure 2. Flow cytometry showing the effect of $A$. membranacea $\mathrm{EO}(\mathbf{A}, \mathbf{B})$ and 1,8 -cineole $(\mathbf{C}, \mathbf{D})$ on cell cycle distribution after $72 \mathrm{~h}$ treatment in A2780 cells. A, C: X-axis: DNA content of 20,000 events, y axis: $\%$ cell number $(n=3$, experiments were repeated $3 \times)$. Statistical differences, compared to untreated control cells, were assessed by a one-way ANOVA with the Tukey's post-hoc multiple comparison test. $\left.p<0.05\left(^{*}\right), p<0.01{ }^{* *}\right)$ and $p<0.001\left(^{* * *}\right)$ were taken as significant. 


\section{Discussion}

The main constituent of the A. membranacea EO analyzed in this study was 1,8-cineole (over $20 \%$ of the total). This monoterpene was also found to be a major constituent of some other Achillea spp., such as A. santolina L. (syn. of Achillea tenuifolia Lam.; 16.7\%) [25], A. tomentosaL. (56.1\%) [26], A. wilhelmsii (syn. of Achillea santolinoides subsp. wilhelmsii (K.Koch) Greuter), A. thracica Velen. (7.46\%-35.72\%) [27] and A. millefolium L. (1.2\%-19.8\%) [28]. Previous studies on 1,8 cineole, or on EOs containing it, reported apoptotic effects on a variety of cancer cell lines, including: SK-MEL-28 (human melanoma); A549 (human lung carcinoma); Colo-205 (Human Caucasian colon adenocarcinoma); (SiHa) cells (human cervical carcinoma); Hep-G2 (hepatocellular carcinoma); MCF-7, T47D, MDA-MB-231 (human breast adenocarcinoma); RKO (Human colon carcinoma); Caco-2 (human Caucasian colon adenocarcinoma); A431 (squamous cell carcinoma); MG-63 (osteosarcoma) and P815 (murine mastocytoma) [29-37]. This study has enriched the list of those cancer cell lines susceptible to 1,8-cineole and EO rich in1,8-cineole, and has demonstrated its potent effect on the ovarian cancer cell line (A2780).

In a previous published study, we reported the marginal cytotoxic effect of the methanol extract of the aerial parts of $A$. membranacea on Jukart cells, with an $\mathrm{IC}_{50}$ value of $60 \pm 5.1 \mu \mathrm{g} / \mathrm{mL}$ [15]. That extract, however, did not exert any cytotoxic effect on MCF7 or A2780 cancer cell lines ( $\left.\mathrm{IC}_{50}>200 \mu \mathrm{g} / \mathrm{mL}\right)$ [23]. The growth of A2780 cells in this study was, however, significantly inhibited $\left(\mathrm{IC}_{50}=12.99 \mu \mathrm{g} / \mathrm{mL}\right) \mathrm{by}$ A. membranacea $\mathrm{EO}$, since the natural product components are generally considered cytotoxic when their $\mathrm{IC}_{50}$ is $\leq 20 \mu \mathrm{g} / \mathrm{mL}$ [38]. The tested EO resulted in the cytotoxicity of the A2780 cell line, while its effect on MCF7was negligible ( $\left.\mathrm{IC}_{50}=50.86 \mu \mathrm{g} / \mathrm{mL}\right)$. In this study, both the EO and 1,8-cineole induced apoptosis in A2780 cells; but 1,8-cineole induced more early apoptosis with minimal late apoptosis and necrosis, compared to a major induction of late apoptosis by the EO at the same time point. The EO also caused 4\%-20\% necrotic events in A2780 cells compared to control cells, indicating the possible effect of other components. The improved cytotoxic and apoptotic activities of 1,8-cineole compared to A. membranacea indicates the possible involvement of one major mechanism of action in $A$. membranacea $\mathrm{EO}$, while the substantial difference between the activities of the EO and the methanol extract of the aerial parts could be due to the difference in the constituents of each extract.

Furthermore, the cell cycle perturbation results of the present work were similar to those observed in a previous study conducted on wild-type p53 H460 cells (but not mutant p53 H460 cells) after the treatment with Achillea millefolium hydroalcoholic extract [39]. Pereira et al. (2018) demonstrated the induction of apoptosis and S-phase arrest, with an increased level of p53 and p21 indicating the different mechanisms involved in the Achillea millefolium extract-induced growth arrest. Likewise, a previous study reported that casticin, a flavonoid extracted from Achillea millefolium, caused $\mathrm{G}_{2} / \mathrm{M}^{\mathrm{m}}$ arrest in HCT116 colon cancer cells, which was confirmed by the induction of p21 and down-regulation of CDK1[14]. However, 1,8 cineole was reported to induce cell cycle arrest in the $\mathrm{G}_{2} / \mathrm{M}$ phase in the HCT116 cell line [30], while the studied $A$. membranacea EO and 1,8 cineole induced preG ${ }_{1}$ increase, which indicate DNA fragmentation and confirm the pro-apoptotic effect in A2780 cells. Further mechanistic studies of the activities of $A$. membranacea components and 1,8 cineole against an array of cancer cell lines are worthwhile, as well as in vivo studies, which will provide more support for their application.

\section{Materials and Methods}

\subsection{Plant Material}

The aerial parts of $A$. membranacea were collected during the spring in the Dab'a desert reserve (50 $\mathrm{km}$ South of Amman), Jordan (GPS coordinates: $31^{\circ} 31^{\prime} 58^{\prime \prime} \mathrm{N}, 36^{\circ} 01^{\prime} 20^{\prime \prime} \mathrm{E}$ ). The plant was identified by Prof. A. Bader. A voucher specimen was deposited in the herbarium of the Pharmacognosy Lab (Number Jo-It 2018/2), at Umm Al-Qura University, Makkah, Saudi Arabia. 


\subsection{Hydrodistillation of the Essential Oil}

The hydrodistillation of $A$. membranacea was performed with a Clevenger-type apparatus equipped with an electric mantle heater (Tecnovetro, Pisa, Italy). A sample (100 g) of air-dried material was hydrodistilled for $3 \mathrm{~h}$. The extraction yield was $0.09 \% \mathrm{w} / \mathrm{w}$.

\subsection{Gas Chromatography-Mass Spectrometry Analyses and Compounds Identification}

The hydrodistilled EO of $A$. membranacea was diluted to $5 \%$ in HPLC-grade $n$-hexane and then injected into a Varian CP-3800 GC-MS apparatus (GC-EI-MS, Varian, Inc. Palo Alto, CA, USA) equipped with a DB-5 capillary column (30 $\mathrm{m} \times 0.25 \mathrm{~mm}$; coating thickness $0.25 \mu \mathrm{m})$ and a Varian Saturn 2000 ion trap mass detector (Varian, Inc. Palo Alto, CA, USA). Analytical conditions were as previously reported [40]. The identification of the constituents was based on the comparison of the retention times with those of authentic samples, comparing their linear retention indices relative to the series of n-hydrocarbons, commercial libraries such as NIST 14 and ADAMS and a homemade mass-spectral library of pure compounds were used to compare the mass spectra [41,42].

\subsection{Chemicals and Reagents}

1,8-Cineole was kindly gifted by Mr. Mohammed Khair Al Halabi, United Tetra Group for Medical and Scientific Supplies, Jordan. Doxorubicin and all reagents were purchased from Sigma-Aldrich, St. Louis, MO, USA.

\subsection{Cell Culture}

Three human cancerous (MCF7, A2780 and HT29) and one fibroblast (MRC5) cell lines were used in this study. Cancer cells were maintained in RPMI-1640, and MRC5 cells were maintained in EMEM media. All media were supplemented with FBS (10\%), sodium pyruvate (1 mM), L-glutamine $(2 \mathrm{mM})$ and penicillin/streptomycin (1\%). Cell cultures were kept on $5 \% \mathrm{CO}_{2}$ in humidified incubator at $37{ }^{\circ} \mathrm{C}$.

\subsection{Cytotoxicity Assay}

Cells were seeded in 96-well plates and exposed to the essential oil of $A$. membranacea at concentrations up to $100 \mu \mathrm{g} / \mathrm{mL}$ for $72 \mathrm{~h}$. 1,8-cineole and doxorubicin concentrations were made up to $50 \mu \mathrm{M}$ also for $72 \mathrm{~h}$. MTT assay was then performed as previously reported [43]. Absorbances were measured using a multi-plate reader at a wavelength $550 \mathrm{~nm}$. $\mathrm{IC}_{50}$ values were determined by calculated the oil concentration-induced 50\% reduction in the absorbance compared to untreated control.

\subsection{Induction of Apoptosis Assay}

The induction of apoptosis activity of $A$. membranacea $\mathrm{EO}$ and 1,8-cineole was investigated by annexin V FITC/Propidium iodide protocol as described in the literature [44]. Briefly, A2780 cells were seeded at $1 \times 10^{5}$ cells/well in 6-well plate overnight before treatment with either $A$. membranacea EO or 1,8-cineole at four concentrations, ranging from 0 to $50 \mu \mathrm{g} / \mathrm{mL}$, or $0-1 \mu \mathrm{M}$, respectively (representing $\mathrm{IC}_{50}: 0, \times 1, \times 2$ and $\times 4$ ). Following treatment, cells were collected (including the supernatant), washed with ice-cold PBS and then incubated for $2 \mathrm{~min}$ in binding buffer $(100 \mu \mathrm{L})$ and annexin V FITC (10 $\mu \mathrm{L})$, at room temperature in the dark. Additional $400 \mu \mathrm{L}$ of binding buffer and $10 \mu \mathrm{L}$ PI were then added. The early apoptotic, late apoptotic, and necrotic cell populations were analyzed by flow cytometry (FC500, Beckman Coulter, Brea, CA, USA), based on 20,000 events per sample.

\subsection{Perturbation of the Cell Cycle}

A2780 cells were seeded at $1 \times 10^{5}$ cells/well in 6-wellplate overnight before being treated with either $A$. membranacea or 1,8-cineole essential oils at four concentrations ranged from 0 to $50 \mu \mathrm{g} / \mathrm{mL}$, or 0 to $1 \mu \mathrm{M}$, respectively. Cells were then suspended by trypsin-EDTA and spun at $200 \times g$ for 5 min. Collected cell pellets were washed in ice-cold PBS before they were fixed in $70 \%$ ice-cold ethanol 
overnight. The cell cycle analysis was then performed and analyzed for 20,000 events per sample, using flow cytometry (FC500, BC, USA), following the protocol described elsewhere $[45,46]$.

\subsection{Statistical Analysis}

Statistical differences of samples, compared to untreated control cells, were assessed by a one-way ANOVA with the Tukey's post-hoc multiple comparison test (GraphPad Prism Version 5, GraphPad Software, San Diego, CA, USA). $p<0.05\left(^{*}\right), p<0.01\left(^{* *}\right)$ and $p<0.001\left(^{* * *}\right)$ were taken as significant.

Author Contributions: Conceptualization, A.B.; methodology, A.N.A., G.F., R.A. and A.B.; software, R.A.; validation, Q.M.A.A. and U.S.; formal analysis, G.F., R.A.; investigation, A.N.A., Q.M.A.A, G.F. and R.A.; resources, U.S; data curation, M.I.S.A.; writing-original draft preparation, A.N.A, G.F., R.A. and A.B.,; writing-review and editing, G.F., R.A. and M.M.B.; supervision, A.B.; project administration, A.B.; funding acquisition, A.B. All authors have read and agreed to the published version of the manuscript.

Funding: This project was funded by the National Plan for Science, Technology and Innovation (MAARIFAH) King Abdulaziz City for Science and Technology, Kingdom of Saudi Arabia, award number (12-MED2310-10) through Science and Technology Unit (STU) at Umm Al-Qura University.

Conflicts of Interest: The authors declare no conflict of interest. The funders had no role in the design of the study; in the collection, analyses, or interpretation of data; in the writing of the manuscript, or in the decision to publish the results.

\section{References}

1. Kwan, Y.P.; Saito, T.; Ibrahim, D.; Al-Hassan, F.M.; Ein Oon, C.; Chen, Y.; Jothy, S.L.; Kanwar, J.R.; Sasidharan, S. Evaluation of the cytotoxicity, cell-cycle arrest, and apoptotic induction by Euphorbia hirta in MCF-7 breast cancer cells. Pharm. Biol. 2016, 54, 1223-1236. [PubMed]

2. Iannuzzi, A.M.; Camero, C.M.; D'Ambola, M.; D’Angelo, V.; Amira, S.; Bader, A.; Braca, A.; De Tommasi, N.; Germanò, M.P. Antiangiogenic Iridoids from Stachys ocymastrum and Premna resinosa. Planta Med. 2019, 85, 1034-1039. [CrossRef] [PubMed]

3. Marsik, P.; Kokoska, L.; Landa, P.; Nepovim, A.; Soudek, P.; Vanek, T. In vitro inhibitory effects of thymol and quinones of Nigella sativa seeds on cyclooxygenase-1- and -2-catalyzed prostaglandin E2 biosynthese. Planta Med. 2005, 71, 739-742. [CrossRef] [PubMed]

4. Zengin, G.; Sarıkürkçü, C.; Aktümsek, A.; Ceylan, R. Antioxidant potential and inhibition of key enzymes linked to Alzheimer's diseases and diabetes mellitus by monoterpene-rich essential oil from Sideritis galatica Bornm. Endemic to Turkey. Rec. Nat. Prod. 2015, 10, 195-206.

5. De Andrade, T.U.; Brasil, G.A.; Endringer, D.C.; Da Nóbrega, F.R.; De Sousa, D.P. Cardiovascular activity of the chemical constituents of essential oils. Molecules 2017, 22, 1539. [CrossRef] [PubMed]

6. Sugier, D.; Sugier, P.; Jakubowicz-Gil, J.; Winiarczyk, K.; Kowalski, R. Essential oil from Arnica montana L. Achenes: Chemical characteristics and anticancer activity. Molecules 2019, 24, 4158. [CrossRef] [PubMed]

7. Attallah, O.A.; Shetta, A.; Elshishiny, F.; Mamdouh, W. Essential oil loaded pectin/chitosan nanoparticles preparation and optimization: Via Box-Behnken design against MCF-7 breast cancer cell lines. RSC Adv. 2020, 10, 8703-8708. [CrossRef]

8. Joyce Nirmala, M.; Durai, L.; Gopakumar, V.; Nagarajan, R. Anticancer and antibacterial effects of a clove bud essential oil-based nanoscale emulsion system. Int. J. Nanomed. 2019, 14, 6439-6450. [CrossRef]

9. Nemeth, E.; Bernath, J. Biological Activities of Yarrow Species (Achillea spp.). Curr. Pharm. Des. 2008, 14, 3151-3167. [CrossRef]

10. Jarić, S.; Popović, Z.; Mačukanović-Jocić, M.; Djurdjević, L.; Mijatović, M.; Karadžić, B.; Mitrović, M.; Pavlović, P. An ethnobotanical study on the usage of wild medicinal herbs from Kopaonik Mountain (Central Serbia). J. Ethnopharmacol. 2007, 111, 160-175. [CrossRef]

11. Kültür, Ş. Medicinal plants used in Kırklareli Province (Turkey). J. Ethnopharmacol. 2007, 111, 341-364. [CrossRef] [PubMed]

12. Aburjai, T.; Hudaib, M.; Tayyem, R.; Yousef, M.; Qishawi, M. Ethnopharmacological survey of medicinal herbs in Jordan, the Ajloun Heights region. J. Ethnopharmacol. 2007, 110, 294-304. [CrossRef] [PubMed]

13. Lev, E. Reconstructed materia medica of the Medieval and Ottoman al-Sham. J. Ethnopharmacol. 2002, 80, 167-179. [CrossRef] 
14. Al-Eisawi, D.M. List of Jordan Vascular Plants. Mitt. Bot. Staatssamml. München 1982, 18, 79-182.

15. Arabaci, T.; Yildiz, B. Taxonomy and threatened categories of three Achillea L. (Asteraceae-Anthemideae) Species Previously cited in the Data Deficient (DD) category. Turk. J. Bot. 2008, 32, 311-317.

16. Bader, A.; Panizzi, L.; Cioni, P.; Flamini, G. Achillea ligustica: Composition and antimicrobial activity of essential oils from the leaves, flowers and some pure constituents. Open Life Sci. 2007, 2, 206-212. [CrossRef]

17. Özek, T.; Tabanca, N.; Demirci, F.; Wedge, D.E.; Başer, H.C. Enantiomeric distribution of some linalool containing essential oils and their biological activities. Rec. Nat. Prod. 2010, 4, 180-192.

18. Çakır, A.; Özer, H.; Aydın, T.; Kordali, Ş.; Çavuşoglu, A.T.; Akçin, T.; Mete, T.E.; Akçin, A. Phytotoxic and insecticidal properties of essential oils and extracts of four Achillea species. Rec. Nat. Prod. 2015, 10, 154-167.

19. Chagas-Paula, D.; Oliveira, T.; Faleiro, D.; Oliveira, R.; Da Costa, F. Outstanding Anti-inflammatory Potential of Selected Asteraceae Species through the Potent Dual Inhibition of Cyclooxygenase-1 and 5-Lipoxygenase. Planta Med. 2015, 81, 1296-1307. [CrossRef]

20. Caliskan, U.K.; Aka, C.; Oz, M.G. Plants used in Anatolian traditional medicine for the treatment of hemorrhoid. Rec. Nat. Prod. 2017, 11, 235-250.

21. Trifunović, S.; Isaković, A.; Isaković, A.; Vučković, I.; Mandić, B.; Novaković, M.; Vajs, V.; Milosavljević, S.; Trajković, V. Isolation, Characterization, and In Vitro Cytotoxicity of New Sesquiterpenoids from Achillea clavennae. Planta Med. 2014, 80, 297-305. [CrossRef]

22. Haïdara, K.; Zamir, L.; Shi, Q.-W.; Batist, G. The flavonoid Casticin has multiple mechanisms of tumor cytotoxicity action. Cancer Lett. 2006, 242, 180-190. [CrossRef] [PubMed]

23. Bader, A.; Abdallah, Q.; Abdelhady, M.; De Tommasi, N.; Malafronte, N.; Shaheen, U.; Bkhaitan, M.; Cotugno, R. Cytotoxicity of Some Plants of the Asteraceae Family: Antiproliferative Activity of Psiadia punctulata Root Sesquiterpenes. Rec. Nat. Prod. 2019, 13, 307-315. [CrossRef]

24. Abdallah, Q.; Al-Deeb, I.; Bader, A.; Hamam, F.; Saleh, K.; Abdulmajid, A. Anti-angiogenic activity of Middle East medicinal plants of the Lamiaceae family. Mol. Med. Rep. 2018, 18, 2441-2448. [CrossRef] [PubMed]

25. Bader, A.; Flamini, G.; Cioni, P.L.; Morelli, I. Essential oil composition of Achillea santolina L. and Achillea biebersteinii Afan. collected in Jordan. Flavour Fragr. J. 2003, 18, 36-38. [CrossRef]

26. Chizzola, R. Composition of the Essential Oil from the Flower Heads of Achillea tomentosa L. J. Essent. Oil Bear. Plants 2018, 21, 535-539. [CrossRef]

27. Yordanova, Z.P.; Rogova, M.A.; Zhiponova, M.K.; Georgiev, M.I.; Kapchina-Toteva, V.M. Comparative determination of the essential oil composition in Bulgarian endemic plant Achillea thracica Velen. during the process of ex situ conservation. Phytochem. Lett. 2017, 20, 456-461. [CrossRef]

28. Farajpour, M.; Ebrahimi, M.; Baghizadeh, A.; Aalifar, M. Phytochemical and Yield Variation among Iranian Achillea millefolium Accessions. HortScience 2017, 52, 827-830. [CrossRef]

29. Darmanin, S.; Wismayer, P.S.; Camilleri Podesta, M.T.; Micallef, M.J.; Buhagiar, J.A. An extract from Ricinus communis L. leaves possesses cytotoxic properties and induces apoptosis in SK-MEL-28 human melanoma cells. Nat. Prod. Res. 2009, 23, 561-571. [CrossRef]

30. Murata, S.; Shiragami, R.; Kosugi, C.; Tezuka, T.; Yamazaki, M.; Hirano, A.; Yoshimura, Y.; Suzuki, M.; Shuto, K.; Ohkohchi, N.; et al. Antitumor effect of 1, 8-cineole against colon cancer. Oncol. Rep. 2013, 30, 2647-2652. [CrossRef]

31. Abu-Dahab, R.; Kasabri, V.; Afifi, F.U. Evaluation of the volatile oil composition and antiproliferative activity of Laurus nobilis L. (Lauraceae) on breast cancer cell line models. Rec. Nat. Prod. 2014, 8, 136-147.

32. Duymuş, H.G.; Çiftçi, G.A.; Yıldırım, Ş.U.; Demirci, B.; Kırımer, N. The cytotoxic activity of Vitex agnus castus L. essential oils and their biochemical mechanisms. Ind. Crops Prod. 2014, 55, 33-42. [CrossRef]

33. Kumar, D.; Sukapaka, M.; Babu, G.D.K.; Padwad, Y. Chemical Composition and In Vitro Cytotoxicity of Essential Oils from Leaves and Flowers of Callistemon citrinus from Western Himalayas. PLoS ONE 2015, 10, e0133823. [CrossRef] [PubMed]

34. Sharifi-Rad, J.; Ayatollahi, S.A.; Varoni, E.M.; Salehi, B.; Kobarfard, F.; Sharifi-Rad, M.; Iriti, M.; Sharifi-Rad, M. Chemical composition and functional properties of essential oils from Nepeta schiraziana Boiss. Farmacia 2017, 65, 802-812.

35. Tundis, R.; Iacopetta, D.; Sinicropi, M.S.; Bonesi, M.; Leporini, M.; Passalacqua, N.G.; Ceramella, J.; Menichini, F.; Loizzo, M.R. Assessment of antioxidant, antitumor and pro-apoptotic effects of Salvia fruticosa Mill. subsp. thomasii (Lacaita) Brullo, Guglielmo, Pavone \& Terrasi (Lamiaceae). Food Chem. Toxicol. 2017, 106, 155-164. [PubMed] 
36. Sampath, S.; Veeramani, V.; Krishnakumar, G.S.; Sivalingam, U.; Madurai, S.L.; Chellan, R. Evaluation of in vitro anticancer activity of 1,8-Cineole-containing $n$-hexane extract of Callistemon citrinus (Curtis) Skeels plant and its apoptotic potential. Biomed. Pharmacother. 2017, 93, 296-307. [CrossRef]

37. Harassi, Y.; Tilaoui, M.; Idir, A.; Frédéric, J.; Baudino, S.; Ajouaoi, S.; Mouse, H.A.; Zyad, A. Phytochemical analysis, cytotoxic and antioxidant activities of Myrtus communis essential oil from Morocco. J. Complement. Integr. Med. 2019, 16, 20180100. [CrossRef]

38. Lee, C.C.; Houghton, P. Cytotoxicity of plants from Malaysia and Thailand used traditionally to treat cancer. J. Ethnopharmacol. 2005, 100, 237-243. [CrossRef]

39. Pereira, J.M.; Peixoto, V.; Teixeira, A.; Sousa, D.; Barros, L.; Ferreira, I.C.F.R.; Vasconcelos, M.H. Achillea millefolium L. hydroethanolic extract inhibits growth of human tumor cell lines by interfering with cell cycle and inducing apoptosis. Food Chem. Toxicol. 2018, 118, 635-644. [CrossRef]

40. Giuliani, C.; Ascrizzi, R.; Tani, C.; Bottoni, M.; Maleci Bini, L.; Flamini, G.; Fico, G. Salvia uliginosa Benth.: Glandular trichomes as bio-factories of volatiles and essential oil. Flora 2017, 233, 12-21. [CrossRef]

41. Adams, R.P. Identification of Essential Oil Components by Gas Chromatography/Quadrupole Mass Spectroscopy; Allured Publishing Corporation: Carol Stream, IL, USA, 1995; ISBN 0-931710-85-5.

42. Davies, N.W. Gas chromatographic retention indices of monoterpenes and sesquiterpenes on Methyl Silicon and Carbowax 20M phases. J. Chromatogr. A 1990, 503, 1-24. [CrossRef]

43. Chahrour, O.; Abdalla, A.; Lam, F.; Midgley, C.; Wang, S. Synthesis and biological evaluation of benzyl styrylsulfonyl derivatives as potent anticancer mitotic inhibitors. Bioorg. Med. Chem. Lett. 2011, 21, 3066-3069. [CrossRef]

44. Gouda, A.M.; Abdelazeem, A.H.; Abdalla, A.N.; Ahmed, M. Pyrrolizine-5-carboxamides: Exploring the impact of various substituents on anti-inflammatory and anticancer activities. Acta Pharm. 2019, 68, 251-273. [CrossRef] [PubMed]

45. Shaheen, U.; Ragab, E.A.; Abdalla, A.N.; Bader, A. Triterpenoidal saponins from the fruits of Gleditsia caspica with proapoptotic properties. Phytochemistry 2018, 145, 168-178. [CrossRef] [PubMed]

46. Attalah, K.M.; Abdalla, A.N.; Aslam, A.; Ahmed, M.; Abourehab, M.A.S.; ElSawy, N.A.; Gouda, A.M. Ethyl benzoate bearing pyrrolizine/indolizine moieties: Design, synthesis and biological evaluation of anti-inflammatory and cytotoxic activities. Bioorg. Chem. 2020, 94, 103371. [CrossRef] [PubMed]

Sample Availability: The starting plant material is available from the authors.

(C) 2020 by the authors. Licensee MDPI, Basel, Switzerland. This article is an open access article distributed under the terms and conditions of the Creative Commons Attribution (CC BY) license (http://creativecommons.org/licenses/by/4.0/). 